\title{
REKONSTRUKSI STRUKTUR TARIAN POJA BERIDENTITIKAN MASYARAKAT BUGIS DI NEGERI SELANGOR
}

\author{
(RECONSTRUCTION OF THE POJA DANCE STRUCTURE \\ TO LINK WITH THE SELANGOR BUGIS IDENTITY)
}

\author{
Khairul Anuar Zainudin \\ k.anuar.zainudin@gmail.com \\ Mohd Effindi Samsuddin \\ effindi@um.edu.my \\ Akademi Pengajian Melayu \\ Universiti Malaya, Kuala Lumpur \\ Malaysia
}

Received: 7th Februari 2021; Accepted: 4th October 2021; Published: 26th October 2021

\begin{abstract}
The development and creation of the traditional Selangor Buginese "Poja" dance in 1988 is a heritage art that has undergone dance reconstruction. The reconstruction is linked to the "Pakurru Sumange" dance in South Sulawesi, Indonesia. Kaeppler's approach to reconstruction (2007) shows that symbols in the "Poja" dance function as a representation of the Buginese community. The study is also based on the theory of creation and tradition by Hobsbawm (1983) and Shill (1981) to understand the relationship between the two aspects of dance involving the traditions of the Bugis community in Selangor. In conclusion, both processes detail the dance's development, therefore allowing its identity to be linked to the Bugis community in Selangor.
\end{abstract}

Keywords: Poja dance, Bugis community in Selangor, reconstruction, dance structure and re-creation of tradition.

\begin{abstract}
Abstrak
Perkembangan dan penciptaan Tarian Poja masyarakat Bugis di Selangor pada tahun 1988 merupakan kegiatan seni tari yang telah melalui proses rekonstruksi semula kesenian tradisi yang berhubung kait dari tarian Pakurru Sumange di Sulawesi Selatan. Pendekatan Kaeppler (2007) tentang pembinaan semula tradisi ini, memperlihatkan simbol dalam Tarian Poja berfungsi mewakili masyarakat Bugis. Teori penciptaan dan tradisi oleh Hobsbawm (1983) dan Shill (1981) digunakan untuk memahami hubungan kedua-dua aspek tarian yang melibatkan tradisi masyarakat Bugis di Selangor. Kedua-dua proses ini memerihalkan perincian latar belakang perkembangan tarian dan menjustifikasikan hubungan identiti Tarian Poja dengan masyarakat Bugis di Selangor.
\end{abstract}

Kata Kunci: Tarian Poja, masyarakat bugis negeri Selangor, rekonstruksi, struktur tari dan penciptaan semula tradisi. 


\section{Pengenalan}

Tarian Poja Bugis Selangor merupakan sebuah tarian yang telah dipersembahkan kali pertama secara rasmi di negeri Selangor bersempena Upacara Perasmian Muzium Sultan Alam Shah pada 2 September 1989 yang telah dirasmikan oleh D.Y.M.M Sultan Selangor Sultan Salahudin Abdul Aziz AlHaj. Mahadzir (2017, p. 24-29) mengatakan bahawa Tarian Poja merupakan sebuah tarian yang sangat popular di Negeri Selangor pada sekitar tahun 1990-an. Namun begitu, sejarah bermulanya tarian ini tidak dapat diketahui secara tepat. Hal sedemikian dikatakan oleh beliau kerana pada masa kini masih ketiadaan bahan maklumat bertulis dijumpai mengenai tarian ini, hanya sekadar penyampaian lisan semata-mata yang dilaporkan dalam penulisan artikel Dewan Budaya yang berjudul Tarian Poja Bugis Selangor.

Apabila tarian ini disampaikan secara lisan melalui pelbagai versi akan turut mencakupi pelbagai aspek seperti sejarah, bentuk, corak, struktrur dan persembahan. Cakupan aspek-aspek ini dilihat menyebabkan berlakunya pelbagai spekulasi dan persepsi terhadap Tarian Poja masyarakat Bugis di Negeri Selangor itu sendiri. Perincian dokumentasi rekod maklumat secara data dan fakta bertulis tidak mempunyai diskripsi latarbelakang yang menyeluruh, namun rekod maklumat dari data sekunder pemerhatian mencatatkan tarian ini terus berkembang dengan sejarah perkembangan yang aktif dengan pelbagai versi dinamik struktur tari. Mohd. Asruddin Bin Selamat (Temu bual peribadi, 2 Disember, 2015) merupakan seorang Pembantu Kanan dan seorang pemuzik Kumpulan Kesenian Muzium Sultan Alam Shah adalah orang pertama mempelajari muzik melalui alat muzik seruling Bugis dalam Kumpulan Kesenian Muzium Sultan Alam Shah yang terlibat secara langsung ketika itu. Beliau mempercayai bahawa Tarian Poja ini berasal dari Tarian Pakkuru Sumange, Sulawesi Selatan ini telah dibawa ke Selangor pada tahun 1988 atas tujuan urusan rasmi kerajaan negeri Selangor. Menurutnya juga bahawa tarian ini dibawa melalui koreografer bernama Andi Ugie Kamariah yang merupakan seorang pereka tari dari Makasar Sulawesi, Indonesia. Tarian Pakkuru Sumange ini telah dibawa untuk Kumpulan Kesenian Muzium Sultan Alam Shah yang kini dikenali sebagai Perbadanan Adat Melayu dan Warisan Negeri Selangor (PADAT). Atas tujuan perkara lawatan daripada Kerajaan Negeri Selangor dalam perkara ke-4 yang digariskan dalam tujuan lawatan, iaitu mengkaji aliran kebudayaan yang berlaku dari Indonesia ke Malaysia dan menerapkan unsur-unsur kebudayaan termasuk adat istiadat, adat resam, pakaian, senibina dan sebagainya khusus di negeri Selangor dari dahulu hingga ke hari ini (Muzium Selangor, 1987).

Proses rekonstruksi dan penciptaan semula tradisi tari yang memperlambangkan tarian tradisi di Selangor mempunyai tujuan dan fungsi tertentu. Walaupun salah satu tujuan rekonstruksi adalah untuk menghidupkan semula sebuah tradisi, hakikatnya proses ini lebih banyak menyaksikan penciptaan semula tari berkenaan (Mohd Anis, 2004, p.159-166). Konteks penyelidikan penulisan ini pada dasarnya menyentuh tentang perkembangan dan proses penciptaan semula tari tradisi melalui sebuah garapan tari yang dikenali sebagai Tarian Poja bagi masyarakat Bugis di negeri Selangor. Tarian ini dilihat sebagai sebuah bentuk penciptaan semula tradisi yang berlaku terhadap bentuk persembahan dan struktur pergerakan yang meliputi gaya pergerakan tari, cara pemakaian busana dan muzik daripada Tarian Pakkuru Sumange pada tahun 1988. 


\section{Sejarah rekonstruksi Tarian Poja di Selangor}

Pada tahun 1987, terdapat satu lawatan rasmi kerajaan negeri Selangor ke Sulawesi Selatan bersempena Lawatan Rasmi Y.A.M Tengku Panglima Diraja Negeri Selangor Darul Ehsan Tengku Sulaiman Shah Al-Haj serta ahli-ahli Lembaga Muzium Negeri Selangor Darul Ehsan Ke Indonesia pada 3 hingga 15 Julai 1987. Terdapat 15 ahli lembaga dan individu penting yang telah mengikuti lawatan ini dalam merapatkan tali silaturrahim antara Negeri Selangor Darul Ehsan dengan Daerah Sulawesi, Indonesia (Muzium Selangor, 1987).

Lawatan dan pertemuan bersejarah keluarga Diraja Y.A.M Tengku Panglima Diraja Negeri Selangor dan kerabat Diraja Sulawesi telah membincangkan mengenai aspek-aspek kebudayaan, sejarah dan juga cadangan untuk menjadikan bandar Ujung Padang sebagai bandar kembar dengan Shah Alam atau Klang. Ketibaan baginda dan para tetamu di Muzium Balla Lampoa dahulunya dikenali sebagai Istana Balla Lampoa telah disambut dengan sebuah tarian selamat datang yang dikenali sebagai Pakkurru Sumange.

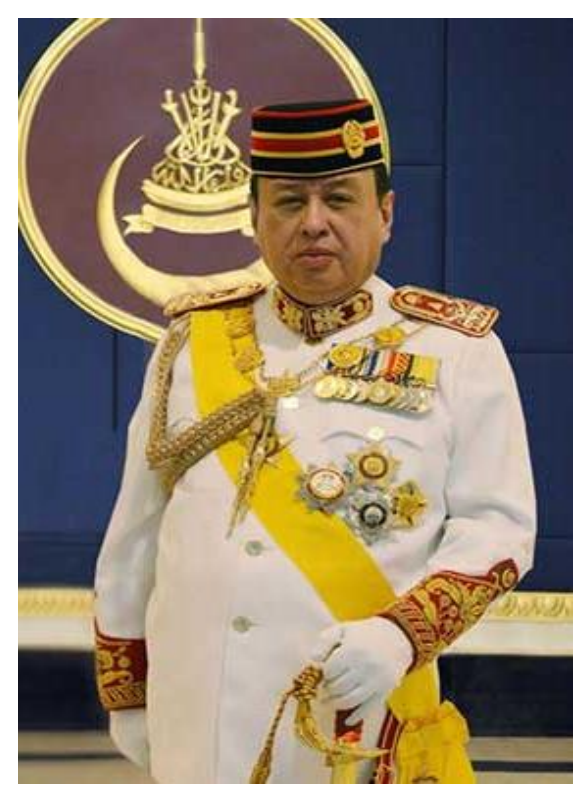

Gambar 1.0: Y.A.M Tengku Panglima Di Raja Selangor Darul Ehsan Tengku Sulaiman Shah AlHaj Ibni Almarhum Sultan Salahuddin Abdul Aziz Shah Al-Haj.

Sumber: Unit Arkib \& Penerbitan Muzium Sultan Alam Shah (PADAT)

Mohd. Asruddin bin Selamat (Temu bual peribadi, Disember 2, 2015) menerangkan bahawa Y.A.M. Tengku Sulaiman dikatakan tertarik dengan persembahan yang ditarikan oleh penari-penari Makassar di Muzium Balla Lampoa. Setelah itu juga, cetusan idea yang diberikan oleh YB. Tuan Haji Kaharudin bin Mokmin dan Dato' Paiman bin Keromo kepada Y.A.M. Tengku Sulaiman untuk membawa masuk tarian 
tersebut ke Negeri Selangor telah diperkenankan bagi tujuan persembahan dan penerapan Tarian Bugis di negeri Selangor.

Berikutan daripada perkenan oleh Tengku Sulaiman, pada tahun 1988 tenaga pengajar bagi Tarian Pakkuru Sumange, iaitu Andi Ugie Kamariah bersama-sama adiknya, Andi Ugie Alinda dan dua orang pemain pemuzik Bugis, iaitu Basri dan Asmar ditawarkan menjadi tenaga pengajar tarian dan muzik Bugis kepada kakitangan PADAT. Tarian Poja ini telah dicipta semula dan diolah daripada Tarian Pakkuru Sumange oleh Andi Ugie Kamariah bagi memudahkan kakitangan perempuan Muzium mempelajari serta menarikan tarian tersebut. Faktor pengolahan gerak tari ini juga disebabkan oleh kerana kakitangan perempuan Muzium Sultan Alam Shah terdiri daripada kakitangan pengurusan dan bukan dari kalangan penari, dan kesukaran melakukan pergerakan tari dengan baik telah dijadikan sebagai aspek garapan olahan.

Terdapat empat jenis Tarian Bugis yang perlu dipelajari, iaitu Tarian Poja (penciptaan semula), Pattenun, Pajoget dan Angin Mamiri. Tujuh orang kakitangan Muzium Sultan Alam Shah telah mempelajari tarian dan muzik masyarakat Bugis dari tahun 1989-1993 yang diajar oleh Andi Ugie Kamariah dan Andi Ugie Haslinda (Sila rujuk Gambar 1.1).

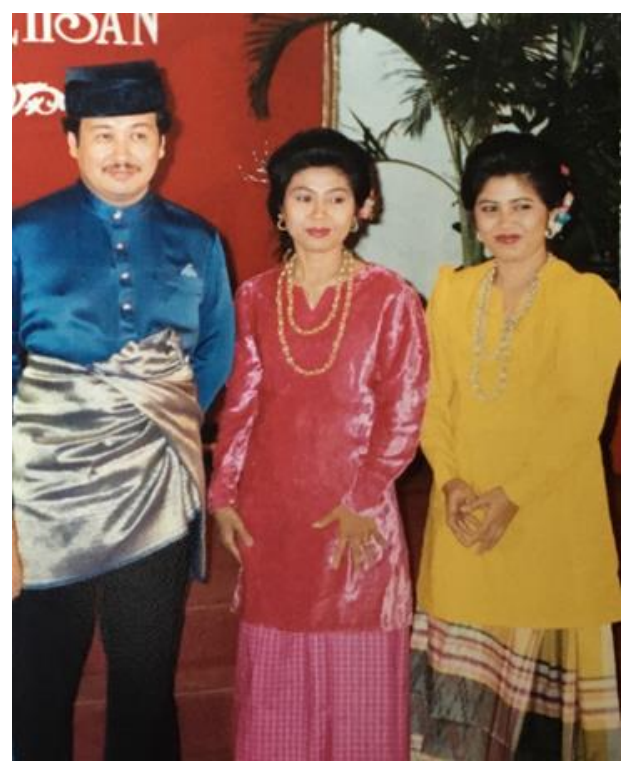

Gambar 1.1: Andi Ugie Kamariah (berbaju merah) dan Andi Ugie Haslinda bersama Y.A.M Tengku Panglima DiRaja Negeri Selangor

\section{Sumber: Unit Arkib \& Penerbitan Muzium Sultan Alam Shah (PADAT}

Begitu juga dengan lima orang kakitangan lelaki yang telah mempelajari cara permainan alatan muzik Bugis pada masa yang sama. Kelima-lima kakitangan lelaki telah mempelajari empat buah jenis lagu, iaitu Pajoget, Angin Mamiri, Pattenun dan Poja. Disamping itu, mereka turut diajar tentang teknik cara pukulan gendang, petikan kecapi, tiupan seruling serta nyanyian dalam bahasa Bugis oleh pembantu muzik Andi Ugie Kamariah, iaitu Basri dan Asmar bagi mengiringi empat jenis tarian tersebut. Keempat- 
empat tarian, iaitu Tarian Poja, Tarian Pattenun, Angin Mamiri dan Pajoget yang diiringi dengan muzik telah dipersembahkan di Majlis Perasmian Muzium Sultan Alam Shah, Selangor pada 2 September 1989.

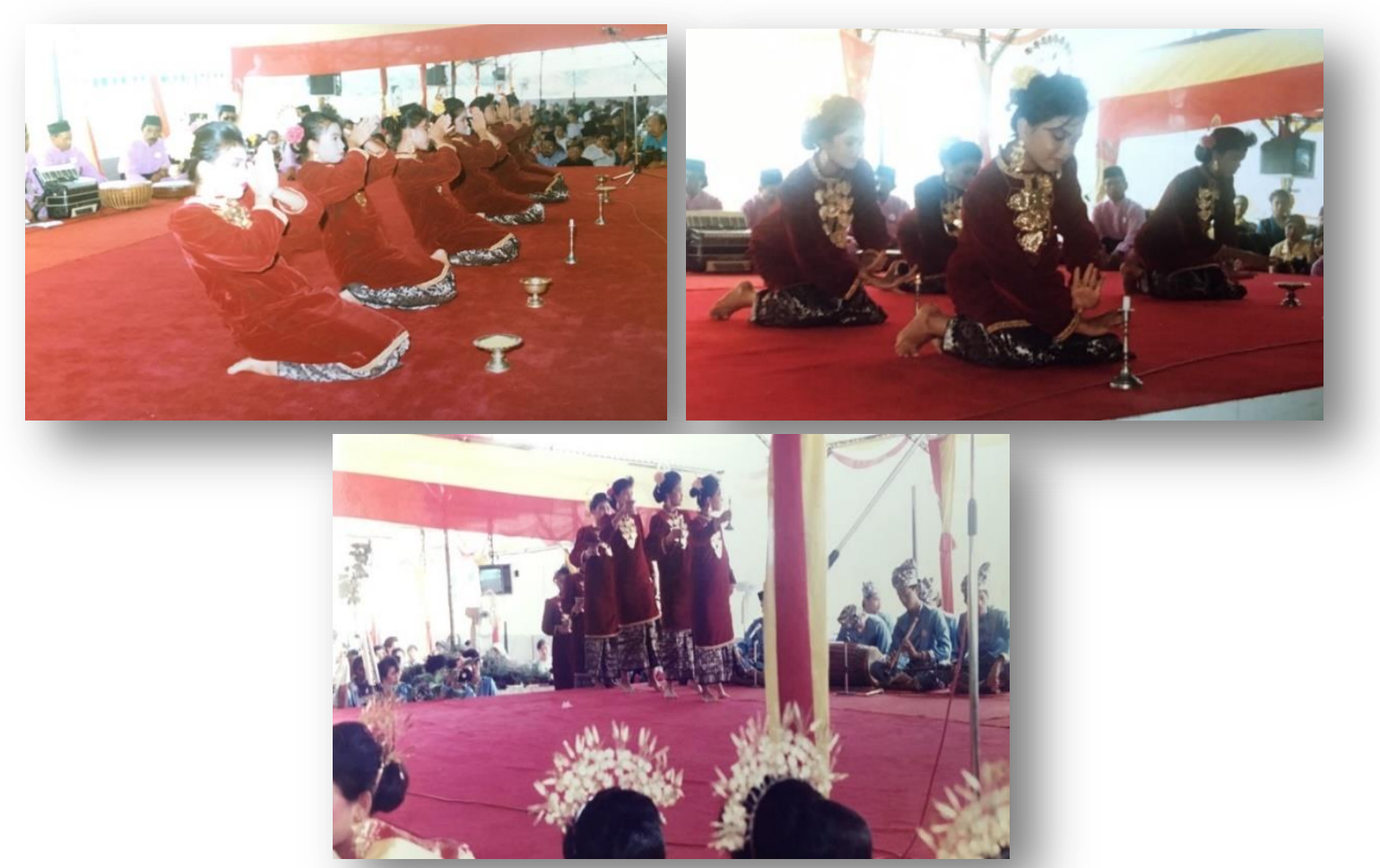

Gambar 1.2: Persembahan Tarian Poja ketika Majlis Perasmian Muzium Sultan Alam Shah

Sumber: Unit Arkib \& Penerbitan Muzium Sultan Alam Shah (PADAT)

Gambar 1.2 dan 1.3 memperlihatkan imejan sambutan upacara perasmian yang berlangsung secara besar-besar dengan dua segmen persembahan. Segmen pertama ialah ketika replika kapal Panisi yang membawa D.Y.M.M Sultan Selangor dan pembesar negeri dengan sembilan buah kapal Bugis berlayar di perairan tasik Raja Lumu Shah Alam menuju hingga ke jeti Muzium Sultan Alam Shah yang turut diiringi alunan muzik instrumental lagu Bugis. Segmen kedua ialah keberangkatan tiba baginda telah disambut dengan perarakan seramai 500 orang ke pintu masuk dan pentas utama Muzium Sultan Alam Shah yang diraikan serta disambut dengan Tarian Poja, Pattenun, Angin Mamiri dan Pajoget.

Mohd. Asruddin bin Selamat (Temu bual peribadi, Disember 2, 2015) mengatakan bahawa upacara perasmian ini telah mendapat liputan khas daripada Rangkaian Televisyen Malaysia (RTM) yang bersiaran secara langsung terus-menerus selama dua jam di kaca televisyen seluruh Malaysia. 

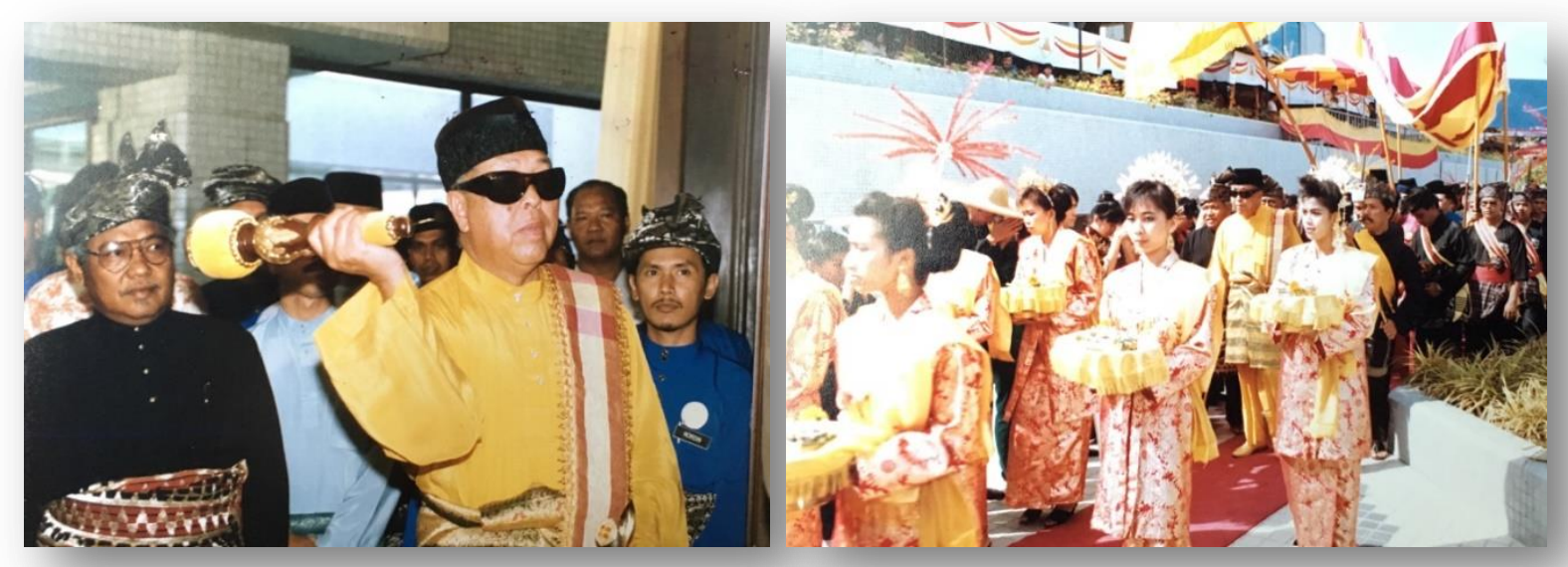

Gambar 1.3: D.Y.M.M Sultan Selangor Salahuddin Abbdul Aziz Alhaj ketika Majlis Perasmian Muzium Sultan Alam Shah

Sumber: Unit Arkib \& Penerbitan Muzium Sultan Alam Shah (PADAT)

\section{$\underline{\text { Rekonstruksi Struktur Tarian Poja }}$}

Kenyataan Hobsbawm (1983) dan Shill (1981) tentang kaitan antara tradisi dan penciptaan semula boleh dikaitkan dengan apa yang berlaku terhadap Tarian Poja. Hobsbawm menjelaskan bahawa penciptaan tradisi merupakan satu set amalan baru yang diterima pakai oleh sesuatu masyarakat dan amalan yang dimaksudkan merujuk kepada perbuatan atau perlakuan yang diterapan, diamalkan, dikerjakan secara berulang-ulang sehingga menjadikannya satu kebiasaan dan berterusan. Shill pula menjelaskan bahawa faktor rasionalisasi menyebabkan perubahan pada tradisi bagi mencapai satu perkara yang rasional dalam membuat perubahan tradisi dengan tujuan untuk meningkatkan mutu atau kualiti sesuatu tradisi secara berterusan. Merujuk kepada penerangan sub-tajuk sejarah atas proses perubahan dan penerusan bagi kesinambungan berlangsung secara terus-menerus dalam Tarian Poja. Perubahan ketara berlaku terhadap bentuk struktur pergerakan dan persembahan berdasarkan fungsi melalui satu proses yang dikenali sebagai rekonstruksi. Mohd. Anis (2004) pula telah mentakrifkan rekonstruksi sebagai sebuah proses pembinaan semula tari daripada konteks tarian asal kepada bentuk penciptaan semula yang merujuk kepada proses baru penciptaan tari kepada satu ruang lingkup atau kawasan persembahan yang berbeza daripada perkara asal disebabkan oleh faktor-faktor tertentu.

Pendekatan analisis struktur pergerakan yang disarankan oleh Kaeppler (2007) digunakan dalam penerangan bagaimana proses struktur analisis dilakukan melalui pergerakan. Analisis struktur pergerakan merupakan analisis morfologi secara terperinci yang melihat hubungan antara bahagian, iaitu aturan yang mengatur atau menyusun perhubungan antara bahagian ke bahagian melalui perspektif horizontal dan vertical. Perspektif ini akhirnya akan menghasilkan aturan pola lantai tari atau pergerakan tari ke dalam struktur pergerakan. Terdapat struktur persembahan secara horizontal yang 
merangkumi tiga bahagian untuk melengkapi sebuah persembahan Tarian Poja, iaitu Sambut Tamu, Raikan Tamu, dan Tanda Kasih (Rujuk Rajah 1.0). Setiap bahagian mempunyai beberapa gerakan yang melambangkan setiap struktur bahagian dalam Tarian Poja Bugis, Selangor.

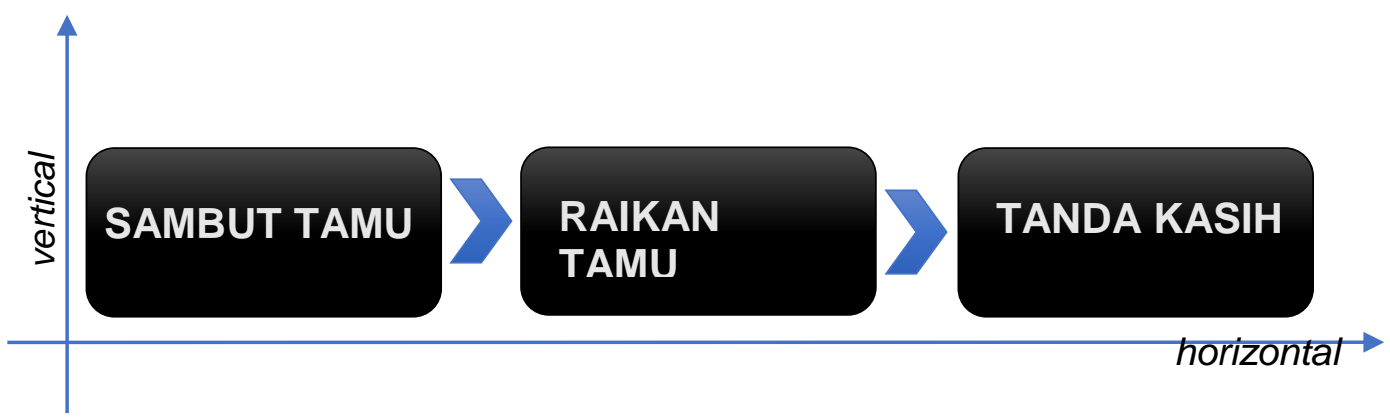

Rajah 1.0: Struktur persembahan Tarian Poja Bugis Selangor

Bahagian Sambut Tamu merupakan frasa permulaan penari masuk ke tengah pentas untuk menyambut dan menghormati tetamu yang hadir dalam majlis tersebut. Penari harus menjengkitkan kaki di samping berlari anak untuk masuk ke tengah pentas sambil memegang dupa di sebelah tangan kanan dan mencubit kain di paha kiri dengan menggunakan tangan sebelah kiri. Penari akan melakukan pergerakan turun ke bawah secara perlahan-lahan setelah melakukan gerakan melayak dan duduk di atas tumit sambil meletakan dupa yang dipegang di hadapan lutut. Setelah meletakkan dupa di hadapan lutut, kedua-dua tangan akan diletakkan di atas paha di sebelah kiri dalam posisi tindih kasih sebelum memulakan pergerakan seterusnya.

Sila rujuk Gambar 1.4 dan Rajah 1.1 untuk melihat visual kedudukan postur, gestur tubuh dan kedudukannya. Terdapat beberapa bentuk motif posisi tangan dan gerakan yang dilakukan dalam Bahagian Sambut Tamu, iaitu seperti lambung angin, kilas angin, ambil bunga, sembah, campak bunga, kaup angin dan turun tangan. Setelah melakukan pergerakan posisi tangan tindih kasih penari akan melakukan pergerakan lambung angin untuk meneruskan pergerakan kilas angin untuk mengambil bunga menggunakan hujung jari. Pergerakan sembah akan dilakukan setelah mengambil bunga di atas dupa dan mencampakkan bunga yang diambil untuk menyambut kedatangan tetamu. Motif pergerakan kaup angin seterusnya dilakukan sehingga tangan diturunkan secara perlahan-lahan. Pergerakan akan diulangi sekali lagi dengan motif pergerakan kilas angin dan seterusnya sehingga ke pergerakan turun tangan selesai.

Dalam Bahagian Raikan Tamu pula merupakan struktur persembahan kedua bagi menyambut dan meraikan tetamu yang hadir dengan mencampakkan dan menaburkan bunga rampai kepada tetamu dalam keadaan yang mempamerkan gestur sopan dan tertib. Terdapat beberapa motif posisi tangan yang dilakukan dalam bahagian ini seperti lambung angin, kilas angin, ambil bunga, sembah, campak bunga, turun tangan, kaup angin, buka kepak dan doa. 
Struktur pergerakan kedua ini juga mengulangi kraf-kraf pergerakan seperti dalam bahagian Sambut Tamu yang dimulai dengan kilas angin setelah melakukan pergerakan lambung angin dan buka kepak sehingga turun tangan. Akhir sekali pergerakan kilas angin akan dilakukan untuk meneruskan pergerakan doa dalam posisi berlutut. Dalam pergerakan posisi tangan, iaitu doa adalah sebuah tanda menghormati dan kesyukuran kepada tetamu yang menghadiri majlis tersebut dengan melambangkan memohon keberkatan daripada Allah snt. Pergerakan motif pergerakan doa akan diakhiri dengan pergerakan sembah duduk bertumit bagi mengakhiri bahagian raikan tamu dalam Tarian Poja. Gambar 1.5 dan Rajah 1.2 menunjukkan visual kedudukan postur, gestur tubuh dan kedudukannya di Bahagian Raikan Tamu.

Struktur bahagian ketiga dan terakhir, iaitu Tanda Kasih merupakan sebuah tanda bermotifkan terima kasih kepada tetamu yang hadir sambil memperlihatkan motif semoga dapat bertemu kembali jika diizinkan Allah di majlis yang akan datang. Penari akan mengambil dupa kembali yang sebelum ini diletakkan di lantai serta di hadapan penari sebelum bangun secara perlahan-lahan setelah melakukan pergerakan lambung angin untuk keluar sambil menaburkan semula bunga rampai yang dibawanya. Penari akan melakukan pergerakan lenggang ombak beralun untuk mengiringi dan menabur bunga rampai di sisi kanan sehingga keluar dengan jengkit lari anak sebagai tanda terima kasih kepada tetamu yang hadir pada majlis tersebut. Sila rujuk Gambar 1.6 dan Rajah 1.3 untuk melihat visual kedudukan postur, gestur tubuh dan kedudukannya

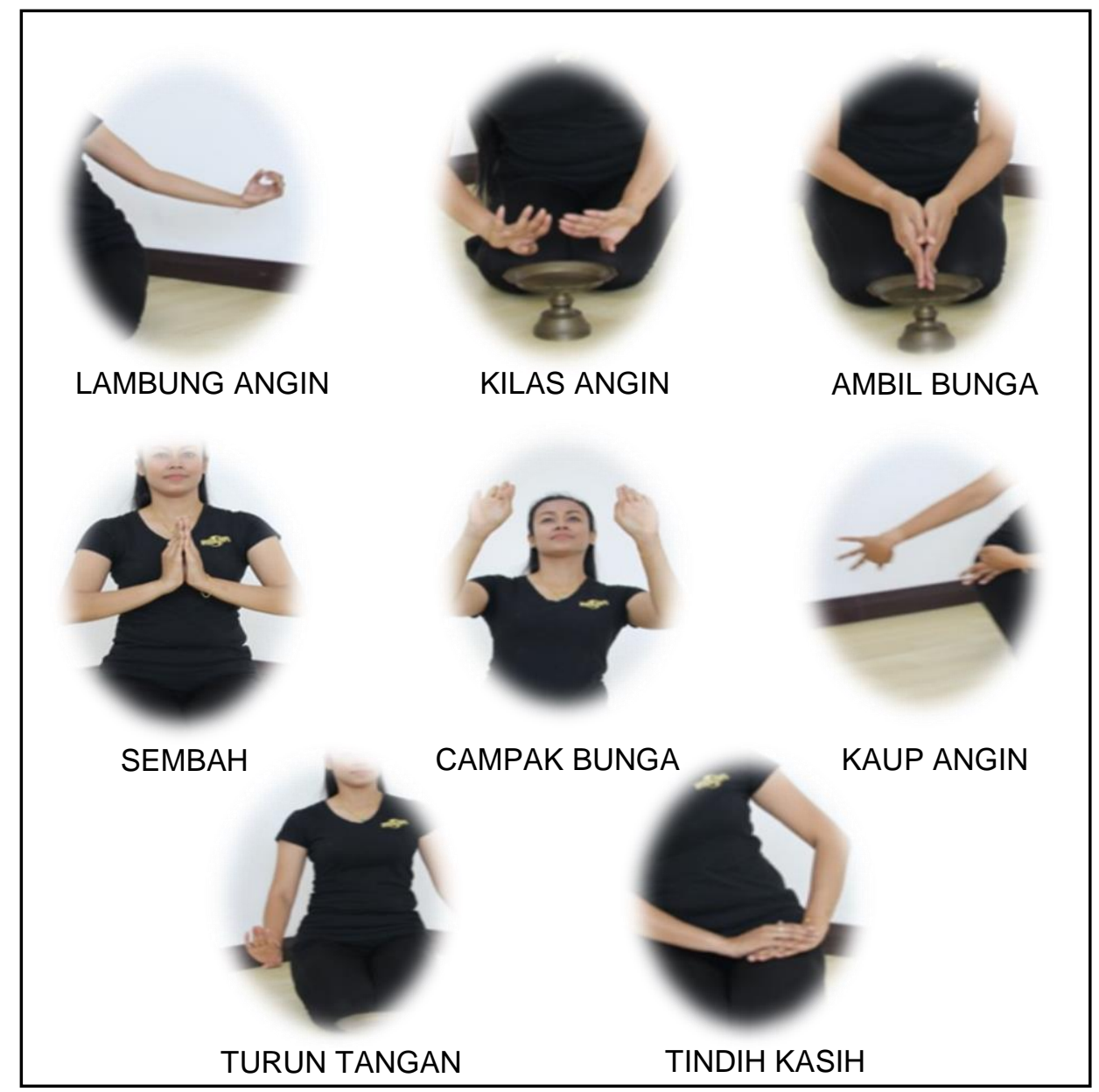

Gambar 1.4: Posisi pergerakan tangan di Bahagian Sambut Tamu 


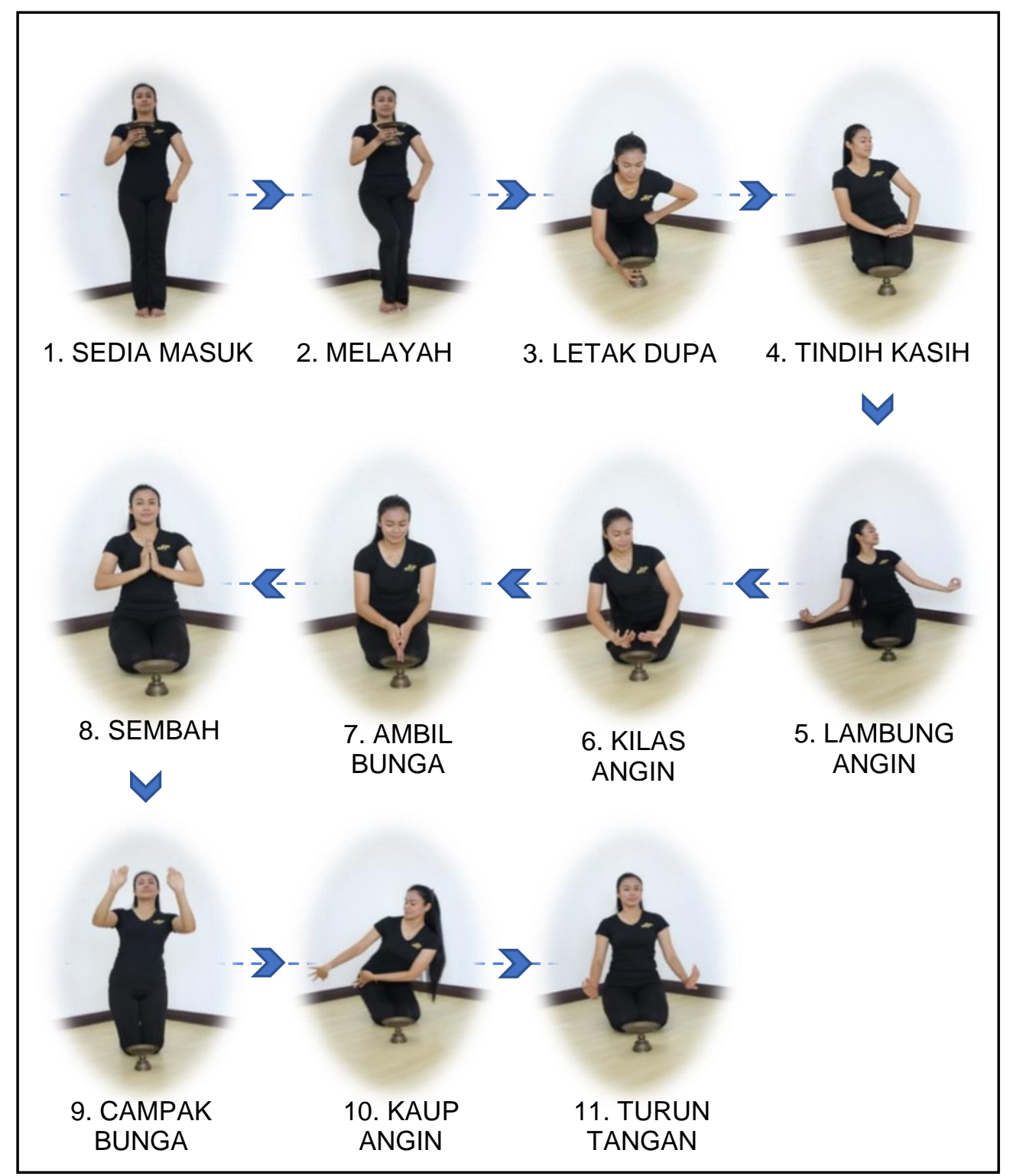

Rajah 1.1: Visual kedudukan postur dan gestur tubuh di Bahagian Sambut Tamu
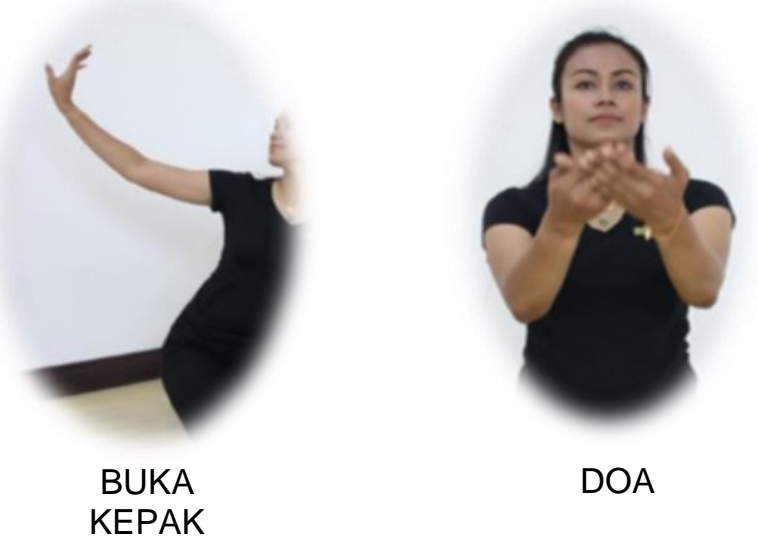

Gambar 1.5: Posisi pergerakan tangan di Bahagian Raikan Tamu 


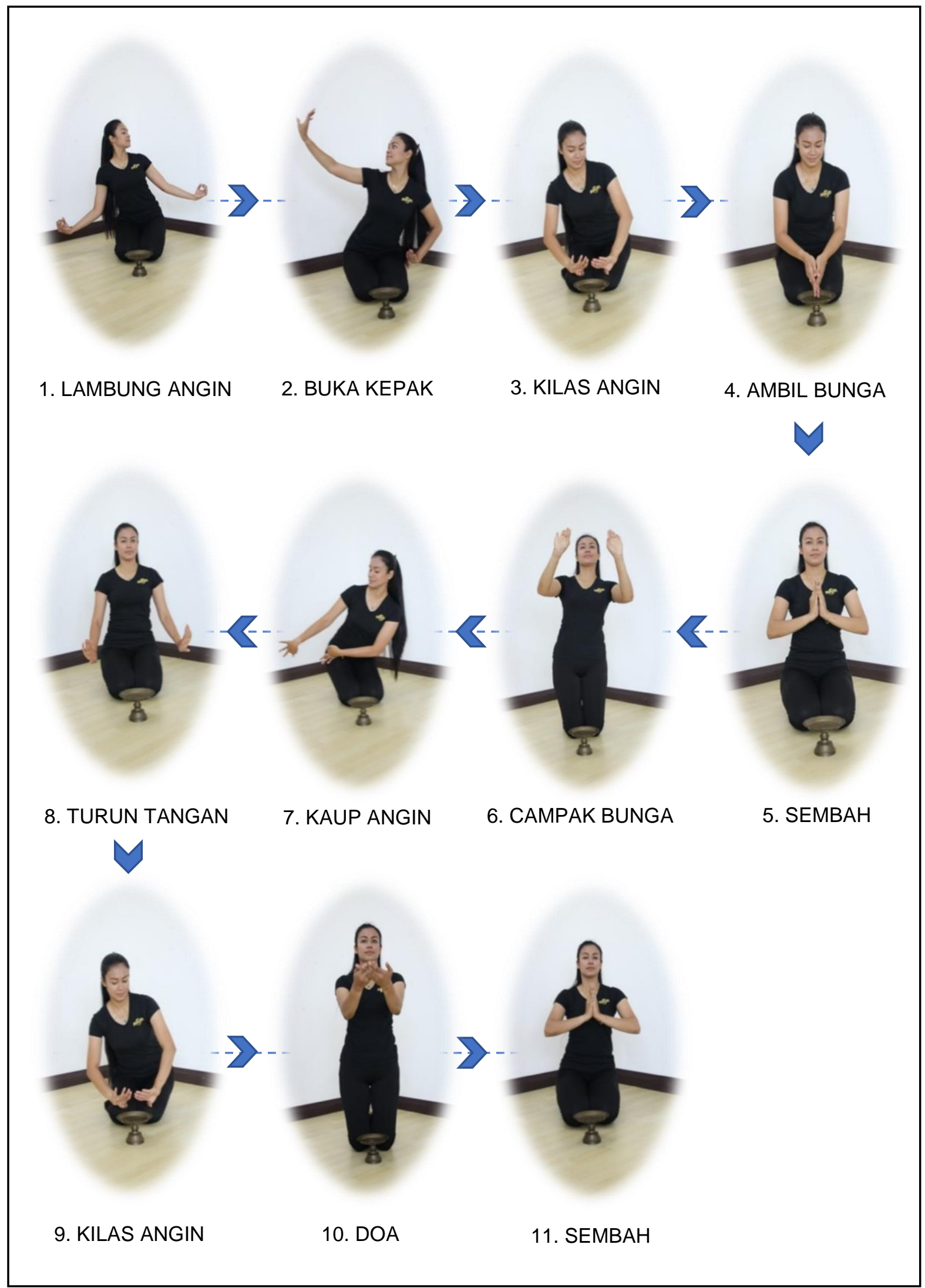

Rajah 1.2: Visual kedudukan postur dan gestur tubuh di Bahagian Raikan Tamu 


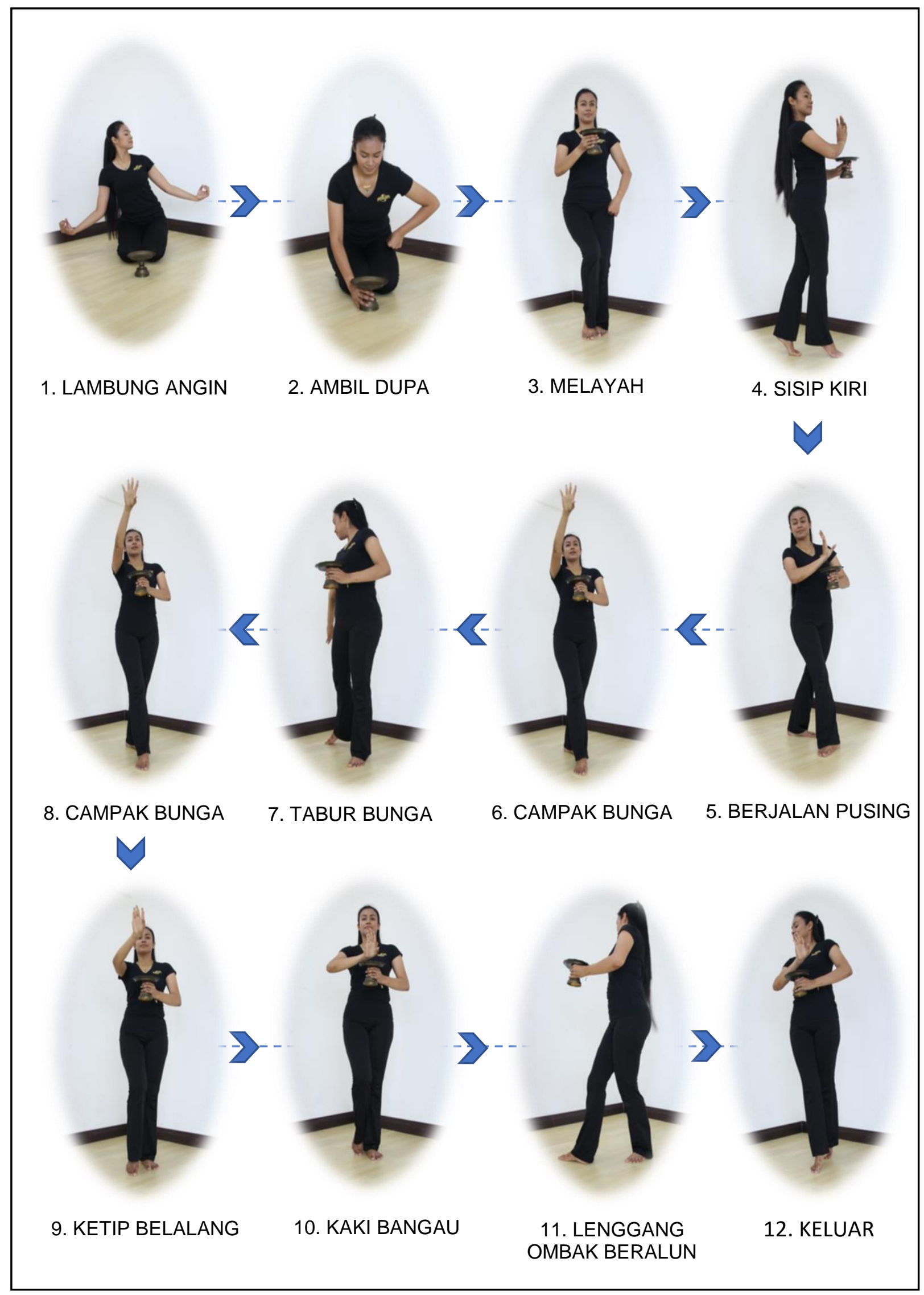

Rajah 1.3: Visual kedudukan postur dan gestur tubuh di Bahagian Tanda Kasih 

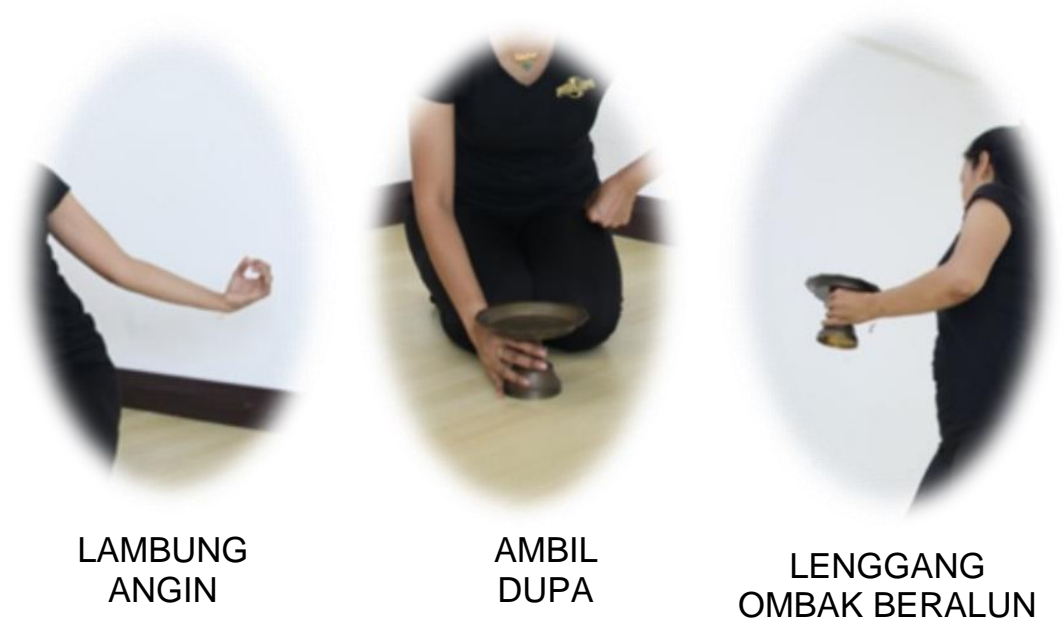

Gambar 1.6: Posisi pergerakan tangan di bahagian Tanda Kasih 


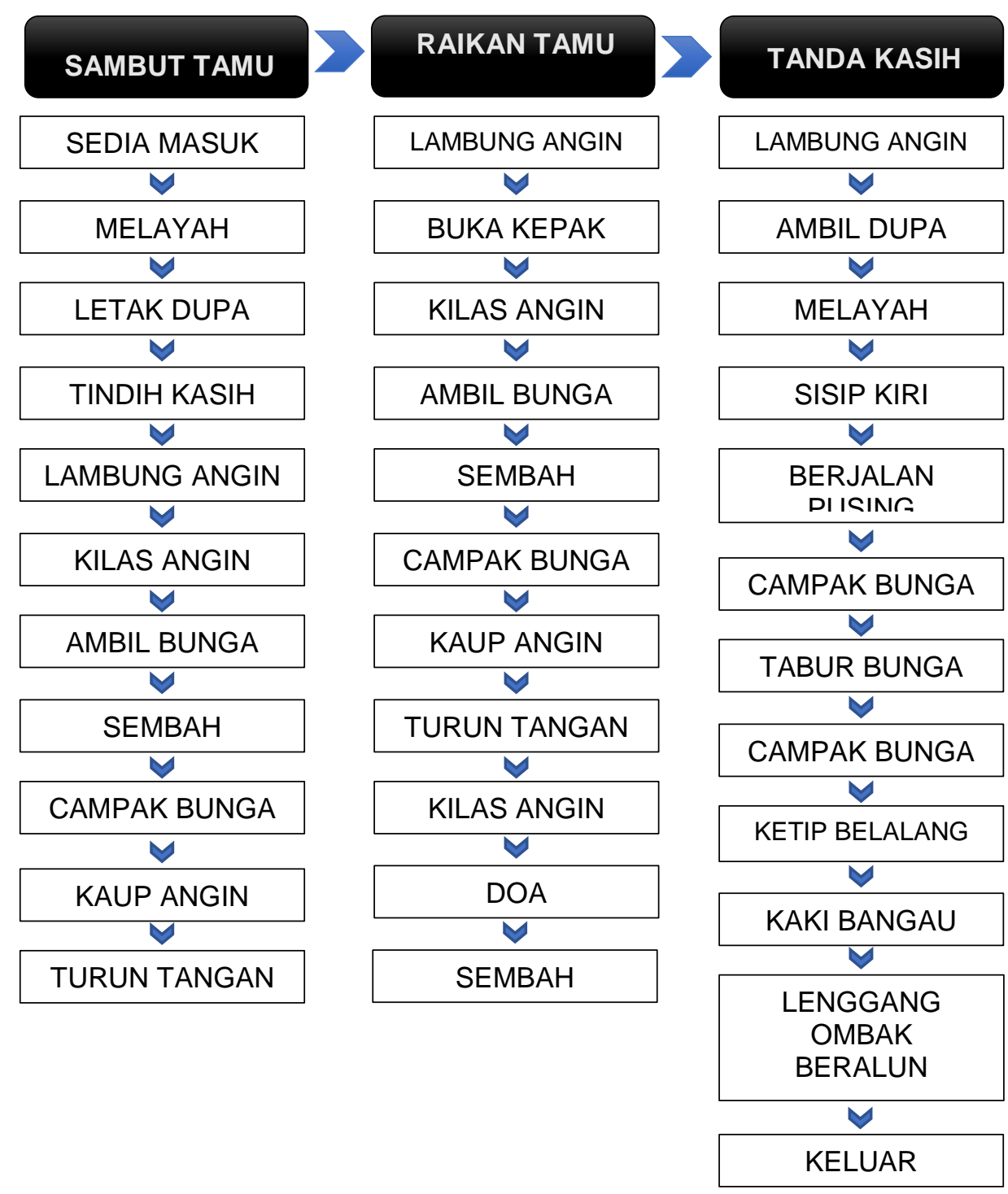

Rajah 1.4: Struktur persembahan dan pergerakan Tarian Poja Bugis Selangor

Rajah 1.4 memperlihatkan secara keseluruhannya tentang fungsi pergerakan lambung angin yang merupakan sebuah pergerakan yang dilakukan sebagai suatu tanda atau simbol pertukaran ke bahagian seterusnya melalui tiga bahagian struktur persembahan Tarian Poja. Terdapat 13 pergerakan posisi tangan yang di gunakan di dalam Tarian Poja Bugis Selangor, iaitu sedia masuk, letak/ambil dupa, tindih kasih, lambung angin, kilas angin, ambil bunga, sembah, campak bunga, tabur bunga, kaup angin, turun tangan, buka kepak dan doa. Manakala dalam pergerakan posisi kaki pula, terdapat sembilan posisi kaki (Gambar 1.6) yang digunakan, iaitu berdiri, berlutut, berjengket, melayah sisi, sisip kiri, kaki bangau, ketip belalang, duduk atas tumit dan duduk berlutut merujuk kepada Jadual 1.0 yang menggariskan susunan pergerakan pada posisi tangan dan kaki dalam Tarian Poja Bugis Selangor. 


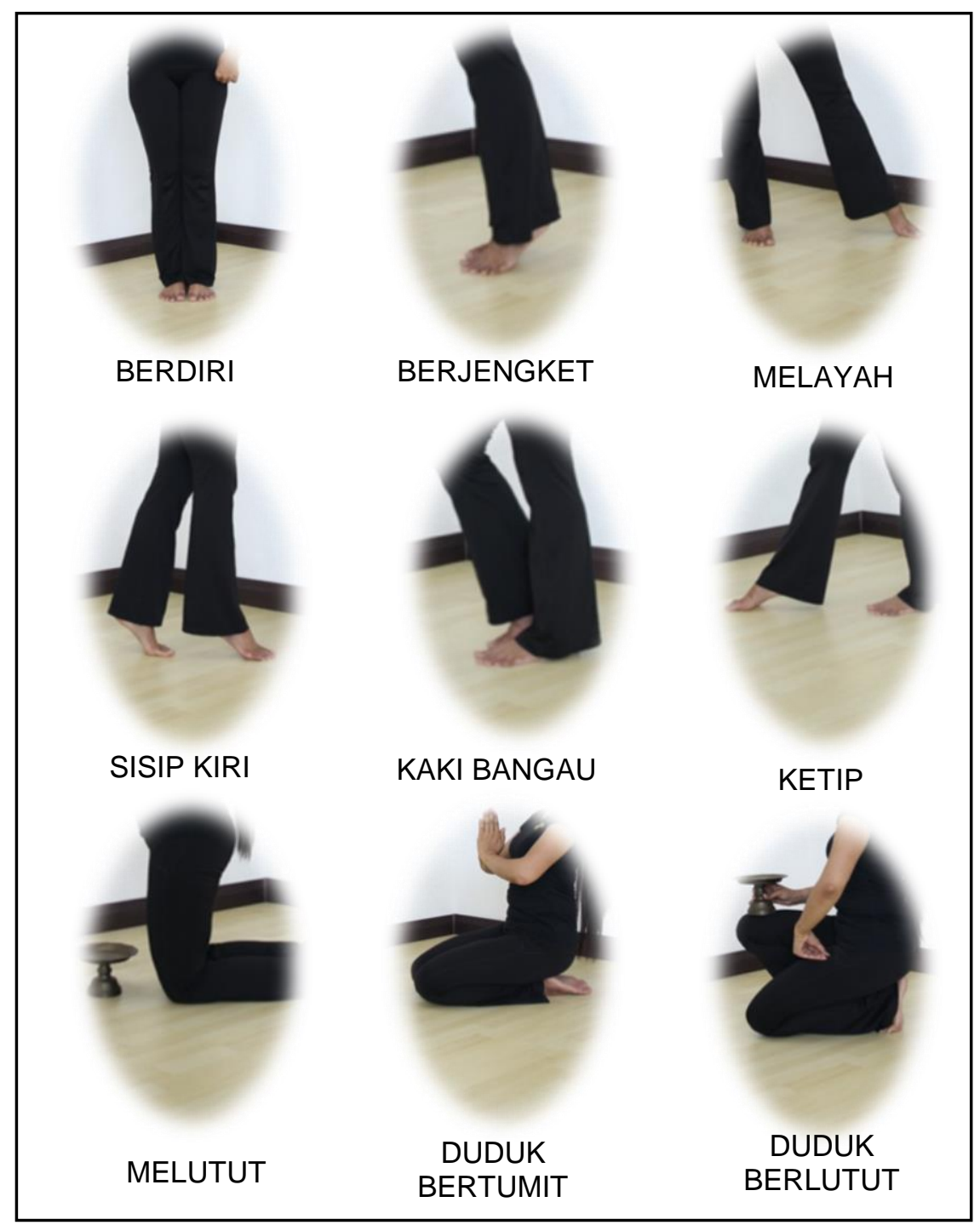

Gambar 1.6: Posisi pergerakan kaki 
Jadual 1.0: Pergerakan dan posisi tarian dan kaki

\begin{tabular}{|c|c|c|}
\hline BIL & PERGERAKAN TANGAN & PERGERAKAN KAKI \\
\hline 1. & Sedia Masuk & Berdiri \\
\hline 2. & Letak/Ambil Dupa & Berjengket \\
\hline 3. & Tindih Kasih & Berlutut \\
\hline 4. & Lambung Angin & Melayah \\
\hline 5. & Kilas Angin & Sisip Kiri \\
\hline 6. & Ambil Bunga & Ketip Belalang \\
\hline 7. & Sembah & Kaki Bangau \\
\hline 8. & Campak Bunga & Duduk Atas Tumit \\
\hline 9. & Tabur Bunga & Duduk Berlutut \\
\hline 10 & Kaup Angin & \\
\hline 11. & Turun Tangan & \\
\hline 12. & Buka Kepak & \\
\hline 13. & Doa & \\
\hline
\end{tabular}




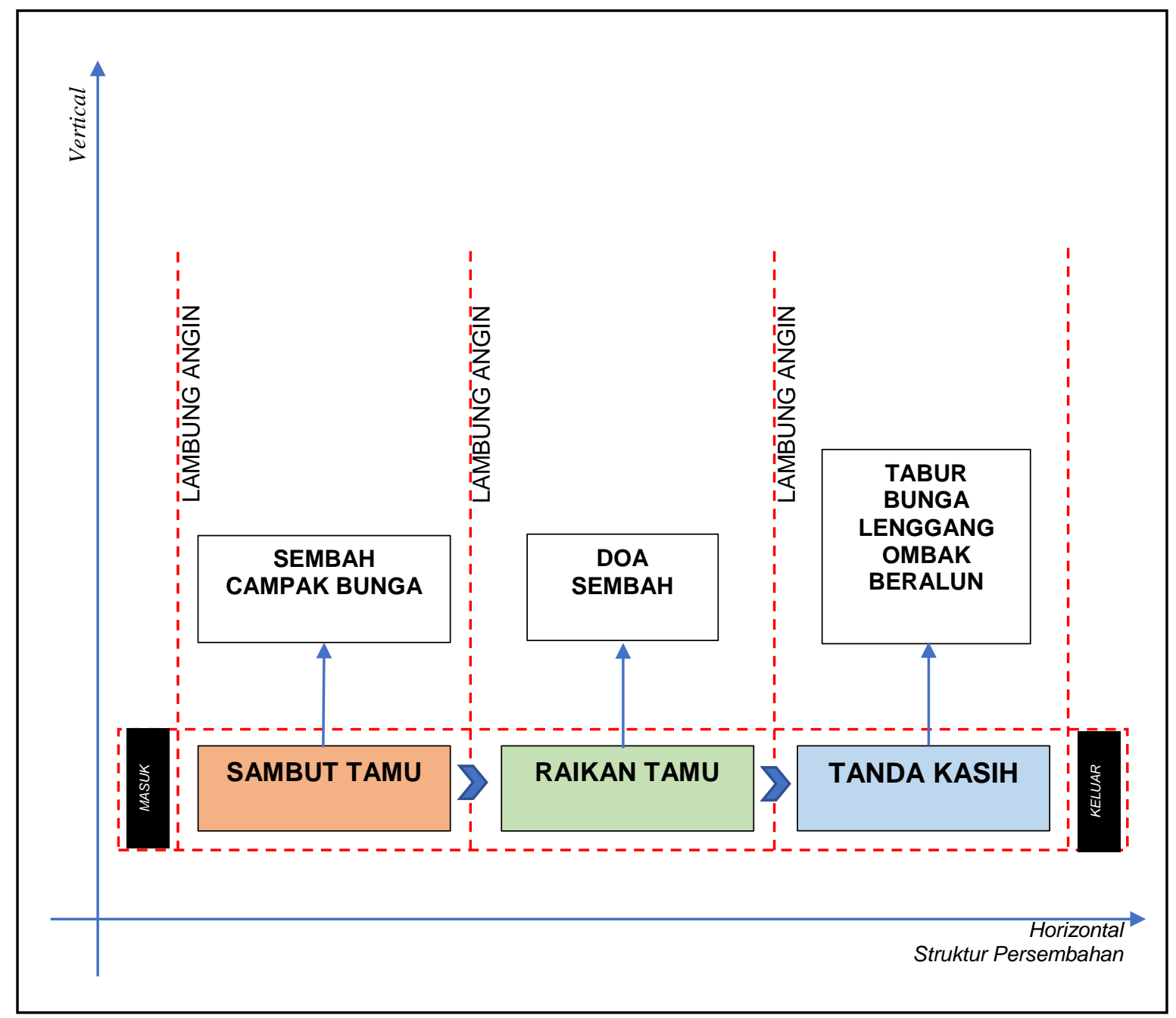

Rajah 1.5: Gaya simbol pergerakan dalam struktur persembahan 


\section{Gaya Simbol Pergerakan Tari}

Gaya merupakan tindakan komposisi gerak tari boleh dibatasi secara tersusun berdasarkan simbol, bentuk dan orientasi nilai yang mendasari sesuatu kreativiti senitari. Bentuk dan simbol ini termasuklah pakaian, bahasa, muzik, tari, jenis rumah dan agama yang digunakan oleh masyarakat atau manusia menandai sebagai identiti mereka sebagai gaya (Royce, 1975, p. 54). Rajah 1.5 merupakan analisis gaya simbol pergerakan yang dapat diklasifikasikan dalam struktur persembahan Tarian Poja. Gaya yang terdapat dalam Tarian Poja dapat dilihat daripada pergerakan yang mempunyai nilai dan ciri-ciri estetika yang tersendiri dalam melakukan pergerakan sembah, lambung angin, campak bunga, doa, lenggang ombak beralun dan tabur bunga.

Analisis struktur persembahan Tarian Poja melalui perspektif horizontal, menunjukkan empat gaya simbol pergerakan yang penting dan perlu diperlihatkan untuk melengkapi pergerakan dalam struktur pergerakan (vertical) pada bahagian struktur persembahan (horizontal). Melalui perspektif vertical, gaya lambung angin merupakan sebuah gerakan yang memberi satu isyarat atau petanda kepada pertukaran dan permulaan setiap pergerakan di bahagian struktur persembahan yang seterusnya. Pergerakan lambung angin akan memberi isyarat pergerakan kepada permulaan gerakan mengikut susunan dan aturan struktur persembahan di Sambut Tamu, Raikan Tamu dan Tanda Kasih.

Bahagian Sambut Tamu, gaya sembah merupakan satu gerakan simbolik sebagai tanda menghormati dan kesetiaan sultan melalui pergerakan tangan yang disampaikan di dalam istana. Ia juga merupakan sebuah gerakan yang utama sering kali dilakukan dalam struktur pergerakan dan persembahan. Gaya campak bunga merupakan sebuah gaya simbol pergerakan yang perlu ada dan dilakukan dengan mencampakkan bunga ke hadapan selepas gerakan sembah dengan tertib dan sopan. Gerakan yang dilakukan dengan mencampak bunga sebagai tanda mengalu-alukan kedatangan tetamu yang hadir dalam suatu majlis dengan bauan aroma wangian bunga rampai bagi memberikan suasana yang segar, tenang dan nyaman di dalam majlis. Salah satu aspek budaya kehidupan masyarakat Bugis adalah nilai adat bagi menciptakan keharmonian, pertimbangan yang merujuk kepada menghormati antara satu sama lain.

Diikuti dengan gaya doa yang merupakan gerakan menadah kedua-dua tapak tangan sebelum gerakan sembah hormat sebagai tanda menghormati dan kesyukuran kepada tetamu yang menghadiri majlis. Seterusnya, gaya lenggang ombak beralun merupakan sebuah gerakan sebelum keluar untuk mengakhiri persembahan bagi mengiringi tetamu yang akan pulang setelah majlis selesai. Gaya tabur bunga merupakan sebuah gerakan menaburkan bunga ke lantai di bahagian sisi kanan sambil melakukan lenggang ombak beralun sebagai tanda terima kasih kepada tetamu yang hadir pada majlis tersebut.

Gaya pergerakan Tarian Poja secara keseluruhannya merupakan pergerakan bercirikan perlahan dan tidak terburu-buru dalam melakukan pergerakan. Pergerakannya ringan dan mudah di dalam melaksanakan pergerakan dan menahan gerakan pada bahagian tertentu. Gaya dan simbol berdasarkan perlambangan motif gerak yang disampaikan di dalam Tarian Poja Bugis Selangor ini, dilihat diterima oleh masyarakat 
Bugis negeri Selangor khususnya dan masyarakat besar lain di Selangor umumnya yang menerima tari ini sebagai satu penanda identiti di Negeri Selangor.

\section{Rekonstruksi dalam struktur persembahan, pergerakan dan identiti}

"Seni dapat diertikan sebagai suatu ilmu yang tersusun, bersistematik dan berfungsi yang dicipta oleh daya fikiran manusia" (Dasuki, 2018). Berdasarkan petikan daripada Dasuki, boleh diertikan dengan merujuk kepada sebuah seni tari yang terdapat di negeri Selangor. Seni Tarian Poja yang telah disusun dan bersistematik melalui rekonstruksi yang telah dilakukan dan dicipta oleh daya pemikiran Andi Ugie Kamariah untuk memberi fungsi kepada tujuan kerajaan negeri Selangor terhadap seni tari di negeri Selangor.

"Penghasilan sesuatu proses yang melibatkan pemikiran amat penting bagi penyelesaian kepada permasalahan dalam reka bentuk. Selain proses memikir, proses yang melibatkan penglihatan merupakan proses bagaimana seniman mendapat idea, manakala membuat pula bererti bagaimana senimam membuat eksperimen secara visual (pandangan) yang berkaitan dengan arah tuju dalam mereka bentuk yang melibatkan rangsangan pemikiran."

(Lauer, 1994)

Berdasarkan kenyataan (Lauer, 1994), penghasilan sesuatu proses tari yang melibatkan reka bentuk sebuah penciptaan adalah berdasarkan idea dan arah tuju penciptaan semula sepertimana yang telah berlaku pada Tarian Poja Bugis di Selangor. Arah tuju atau tujuan penciptaan yang berlaku pada kewujudan Tarian Poja adalah disebabkan oleh beberapa faktor yang melibatkan usaha yang dihasilkan dan dilakukan oleh kerajaan Selangor pada tahun 1989. Dalam konteks penghasilan ini melibatkan motivasi pemikiran bagi menyelesaikan masalah atau isu negeri yang melibatkan perihal idientiti tersendiri di negeri Selangor berbanding dengan negeri-negeri lain di Malaysia.

Tarian Poja merupakan sebuah proses penciptaan dan pembentukan identiti proses menjadi (identity as becoming) sebagai sebuah identiti budaya dan tarian dalam masyarakat Bugis di negeri Selangor yang telah dijelaskan dan ditakrifkan oleh Stuart Hall sebagai sebuah budaya bersama yang mempunyai sejarah dan keturunan yang sama. Identiti merujuk kepada pemerihal yang mempengaruhi perasaan untuk merasakan sebahagian daripada kelompok budaya asal yang ingin memiliki kesamaan sejarah dan keturunan yang sama daripada masyarakat atau bangsa Bugis dari Sulawesi Selatan.

Isu terhadap sejarah dan identiti ini pernah diterbitkan dalam artikel Dewan Budaya Bil.6/2017 bertajuk "Tarian Poja Bugis Selangor" yang ditulis oleh Syed Mahadzir (2017) terbitan Dewan Bahasa dan Pustaka. Mahadzir (2017) menyatakan bahawa Tarian Poja merupakan Tarian Bugis yang sangat popular di Selangor. Namun begitu, sejarah bermulanya tarian ini tidak dapat diketahui secara tepat. Hal ini dikatakan demikian kerana ketiadaan bahan bertulis mengenai tarian ini hanya sekadar penyampaian lisan semata-mata. 
Hasil dapatan kajian yang diperolehi berdasarkan analisis temu bual, pemerhatian dan penelitian dokumen sejarah Tarian Poja dapat dikenal pasti secara berperingkat. Sejarah perkembangan Tarian Poja pada tahun 1988 yang ditafsir melalui analisis Teori Identiti Budaya oleh Hall (1990) mendapati bahawa berlakunya satu proses pembentukan identiti budaya di negeri Selangor tanpa disedari berlaku seperti yang tercatat dalam tujuan lawatan perkara ke-4 (Muzium Selangor, 1987, p. 34) yang merujuk kepada lawatan yang berlangsung pada tahun 1987 oleh pihak kerajaan negeri Selangor ke Indonesia.

Proses pembentukan identiti budaya berlaku secara tidak langung di negeri Selangor atas faktor dalaman dan tujuan lawatan kerajaan negeri yang telah menjalankan kajian aliran kebudayaan Bugis yang berlaku dari Indonesia telah berhasil menerapkan perhubungan unsur-unsur kebudayaan Bugis termasuk adat resam, pakaian, senibina dan sebagainya di negeri Selangor. Apabila berlakunya proses pembentukan tersebut, kerajaan negeri Selangor telah mengalami satu pembentukan proses menjadi identiti (Identity as becoming) yang tercetus atas faktor dalaman untuk mencari dan menginginkan kesatuan bersama dalam kebudayaan seperti yang telah dinyatakan oleh Hall (1991).

Hall (1991) menghubungkan pengertian identiti dalam budaya itu bukanlah suatu perkara yang jelas dan sesuatu yang tidak pernah selesai yang senantiasa dalam proses berterusan dan berpanjangan. Identiti yang dimaksudkan adalah satu proses konstruksi atau pembentukan yang berkaitan dengan tujuan dan penggunaanya. Hall juga menyatakan identiti budaya adalah persoalan tentang bagaimana seseorang membentuk dirinya atau kelompok membentuk kumpulannya melalui kewujudan identiti (identity as being) atau proses menjadi identiti (identity as becoming).

Penentuan identiti turut melibatkan reka bentuk yang tergolong kepada dua perkara iaitu produk dan proses. Produk selalunya dikaitkan dengan hasil, manakala proses pula ialah perancangan, pengelolaan untuk memenuhi matlamat, perlaksanaan menurut tujuan tertentu dan penciptaan.

"Reka bentuk ialah unsur yang menpunyai kaitan dengan fungsi gunaan dan juga fungsi hiasan yang melibatkan proses. Berkaitan dengan fungsi gunaan, reka bentuk yang dihasilkan dalam sesuatu bidang atau perkara lebih menjuruskan kepada proses penghasilan sesuatu yang dapat dihayati dan dipraktikkan."

(Lawson, 1994)

Berdasarkan kenyataan di atas reka bentuk dapat dikaitkan dengan penciptaan Tarian Poja berdasarkan kenyataan bahawa sesuatu produk atau hasil daripada penciptaan atau penghasilan proses sesuatu bidang atau perkara yang dijalankan dapat dihayati dan dipraktikkan melalui perkongsian terhadap tarian ini yang tercetus berdasarkan kepentingan pendukungnya. Jika dilihat identiti budaya masyarakat Bugis melalui Tarian Poja telah terus digiatkan selama 32 tahun semenjak mula digubah melalui kaedah rekonstruksi tari melalui inisiatif kerajaan negeri Selangor yang menerapkan unsur-unsur seni budaya Bugis di negeri Selangor pada tahun 1987. 
"Kemodenan dalam konteks peradapan manusia adalah suatu perubahan yang membawa kepada pengingkatan kualiti hidup. Budaya ekspresif tidak boleh dipisahkan daripada berbagai-bagai bidang lain seperti ekonomi, politik dan sosial yang mempengaruhi keseluruhan kehidupan anggota masyarakat. Proses perubahan yang dilalui anggota masyarakat turut mempengaruhi kedudukan penghasilan unsur-unsur budaya ekspresif. Melalui unsur-unsur budaya ekspresif itu menerangkan penyataan dan simbolik budaya."

(Kadir, 2007)

Berdasarkan kenyataan Kadir (2007), tradisi tidak akan berubah sendiri kerana mempunyai potensi untuk berubah mengikut arus kemodenan melalui masyarakat pendukungnya sendiri sebagai sumber ejen penerusan dan pengulangan kepada kehidupan sosial dan budaya. Unsur-unsur budaya ekspresif merupakan sebahagian daripada kehidupan anggota masyarakat. Peranan dan kepentingannya bukan sahaja sebagai hiburan dan mengisi masa lapang, malahan juga sebagai saluran yang dapat memupuk nilai-nilai sosial.

Tarian Poja adalah sebuah tarian tradisi daripada masyarakat Bugis di Sulawesi yang melalui proses kemodenan bagi mencapai matlamat yang diinginkan oleh kerajaan. Tarian yang telah dicipta dan diolah oleh Andi Ugie Kamariah sebagai tindak balas terhadap pemerintahan kerajaan negeri Selangor untuk menjadikan sebahagian identiti budaya tari tempatan di negeri Selangor pada tahun 1988. Tarian Poja telah memberi satu impak kepada perkembangan tarian lain di negeri Selangor sebagai wadah untuk proses penciptaan tarian baru.

"Isi utama yang menyebabkan perkembangan corak kerja kreatif berlaku melalui faktor perubahan-perubahan yang terus tercetus disebabkan dari corak pemikiran masyarakat yang kian terbina dan terdedah dengan pelbagai pembangunan ilmu, persilangan budaya, ekonomi dan peluang-peluang baru yang melanda dalam kehidupan pramoden."

(Mohd Effindi Samsuddin, 2007)

Seperti yang dipetik oleh Mohd Effindi Samsuddin, Tarian Poja juga boleh dilihat disebabkan berlakunya perkembangan corak kerja kreatif melalui beberapa faktor iaitu politik dan identiti dengan penghasilan dan penciptaan sebuah Tarian Poja di negeri Selangor. Tarian Poja juga melalui sebuah proses penciptaan semula dan rekonstruksi pengembangan daripada bentuk yang asal ke bentuk baru namun stuktur pergerakan dan persembahan masih memperlihatkan ciri-ciri budaya Bugis yang diterima, diiktiraf dan terus berlangsung di Selangor selama 32 tahun.

Rekonstruksi khazanah seni ini melalui penciptaan semula tradisi bukan sahaja berlaku terhadap bentuk persembahan dan struktur pergerakan, malah nama tarian turut membantu dalam proses penciptaan nama Tarian Poja yang dilakukan oleh Andi Ugie Kamariah. Penciptaan semula dari sudut pengistilahan juga telah berlaku, perkataan Poja tidak wujud di dalam lingustik bahasa Bugis di Sulawesi Selatan dan Kamus Besar 
Bahasa Indonesia (KBBI). Namun penciptaan nama Poja telah diwujudkan dan diambil daripada suku kata "puja" yang membawa maksud puja-memuja dan puji-pujian yang sekali gus menolak andaian bahawa puja yang dimaksudkan mempunyai kaitan dengan unsur ritual dan keagamaan. Aspek ini juga atas sebab penciptaan nama tarian berdasarkan perkataan "puja" dalam bahasa Bugis di Sulawesi Selatan bermaksud suka atau senang. Perasaan suka atau senang memberi simbolik kepada sesuatu rasa atau perasaan berbesar hati untuk menyambut kehadiran tetamu. Unsur pengaruh politik yang tercetus pada awalnya telah berkembang dari masa ke semasa dan disambut baik oleh masyarakat dan penduduk Selangor. Namun begitu, persembahan Tarian Poja ini yang bersifat dan berbentuk tradisi dilihat oleh kajian akan terus menjadi suatu kepentingan dalam majlis rasmi kerajaan dan majlis keramaian dalam masyarakat Bugis di negeri Selangor.

\section{Kesimpulan}

Penyelidikan terhadap perkembangan kerja kreatif dan pencetusan Tarian Poja Bugis Selangor dijalankan bagi mendapatkan ketepatan fungsi gerak tari yang direkonstruksi semula daripada tarian tradisional masyarakat Bugis di Sulawesi Selatan Indonesia, iaitu Tarian Pakurru Sumange dalam mempamerkan kesan garapan dan estetika gerak bercorak tempatan. Malah melalui kajian ini turut membolehkan pelbagai pihak termasuk penggiat, penggarap, penyelidik, pelajar, masyarakat umum negeri dan negara serta generasi masa akan datang mengetahui asal-usul tarian ini. Kajian ini memberikan perincian input keilmuan konsep rekonstruksi melalui proses penciptaan semula dalam garapan tari yang berlatarbelakangkan masyarakat Bugis khususnya di negeri Selangor yang telah dicetuskan seawal tahun 1988. Corak dan faktor kepentingan hubungkait antara konsep garapan dan identiti yang telah dilihat sebagai sumbangan kepada badan ilmu seni tari khususnya di Selangor dan umumnya di Malaysia. Selain itu, kerja rekonstruksi dalam garapan kualiti gerak perbendaharaan menjadi bahan dokumentasi dapat memperlihatkan gerakan yang mempamerkan hubungan teknik kod (codified technique) yang terdapat pada tari ini yang dikaitkan dengan masyarakat Bugis di negeri Selangor. Motivasi ini juga dapat dilihat sebagai usaha untuk menjadi pendorong kepada Kerajaan Negeri Selangor dan PADAT untuk perlu terus memberi perhatian terhadap perkembangan dan penerusan nilai budaya negeri ini.

Kajian ini turut berkepentingan dalam memberi perhatian terhadap inisiatif yang positif kepada kerajaan negeri Selangor yang bertanggungjawab memperkayakan sejarah perkembangan tari dalam wadah dinamik melalui usaha awal yang telah dilakukan pada 32 tahun yang lalu. Usaha melestarikan tari ini juga perlu dilakukan agar tidak pupus serta dapat memperkenalkan Tarian Poja Bugis Selangor kepada generasi-generasi baru yang akan datang, dan juga sebagai pemangkin penerusan pengkajian nilai budaya dilakukan sebagai usaha mempertingkatkan rujukan kesenian dan kreatif dikendalikan serta terus mendapat perhatian di negeri Selangor. 


\section{Rujukan}

Haziah Hussin, Salmah Abu Mansor, Rahilah Omah, Hapsah Ismail \& Aminuddin Hassan. (2009). Seni, seni hias, seni reka, reka bentuk dan estetika daripada persepsi umum dan Orang Melayu. Jurnal Pengajian Melayu / Journal of Malay Studies (JOMAS), 20 (1), pp. 82-98.

Hobsbawm, E. \& Ranger, T. (1983) The Invention of Tradition. United States of America: Cambridge University Press.

Kaeppler, A. L. (2007). Dance Structures Perspectives On The Analiysis of Human Movement. Canada: Akademia Kiado.

Kaeppler, A. L. (2007). Method and theory in analyzing dance structure with a Tonga Dance. Kaeppler, Adrienne L. \& Dunin Ivancich. Ed. Dance Structures: Perspective in the Analysis of Human Movement, Budapest: Academia Kiado, pp. 56-62.

Mahadzir, S. (2017). Tarian Poja Bugis Selangor. Dewan Budaya, 6, 2017, pp. 24-29.

Mohd Anis Md Nor. (ed.) (2000). Zapin Melayu di Nusantara. Johor: Yayasan Warisan Johor.

Mohd Effindi Samsuddin. (2007). Perubahan Corak Kerja Kreatif Bangsawan: Satu Kesinambungan Identiti. Jurnal Pengajian Melayu / Journal of Malay Studies (JOMAS), 18 (1), pp. 57-85.

Muzium Selangor. (1987). Lawatan resmi Yang Amat Mulia Tengku Panglima Di Raja Negeri Selangor Darul Ehsan Tengku Sulaiman Al Haj. Shah Alam: Lembaga Muzium Negeri Selangor Darul Ehsan.

Pelras, C. (2006). Manusia Bugis. Jakarta: Nalar.

Royce, A. P. (1977). The anthropology of dance. Bloomington: Indiana University Press.

Schils, E. (1981). Tradition. Chicago: The University of Chicago Press.

Sutton, R.A. (2013). Pakkurru Sumange: Musik, tari dan politik kebudayaan Sulawesi Selatan. Indonesia: Ininnawa.

Wan Abdul Kadir. (2007). Antara tradisi dan perubahan pernyataan budaya di persisiran Pantai Timur Semenanjung Malaysia. Jurnal Pengajian Melayu / Journal of Malay Studies (JOMAS), 18(1), pp. 172-185.

Wan Mohd Dasuki. (2018). Meor Abdul Rahman: Konsep Tempur Seni Gayong dan Inovasi Silat Melayu. Jurnal Pengajian Melayu / Journal of Malay Studies (JOMAS), Jilid 29, pp. 237. 